\title{
PENERAPAN MEDIA GAMBAR SERI DALAM KETERAMPILAN MENULIS CERITA DI MADRASAH IBTIDAIYAH DARUL ILMI BANJARBARU
}

Oleh:

\section{Tutus Rani Arifa}

\author{
Program Studi Pendidikan Guru Madrasah Ibtidaiyah, Fakultas Studi \\ Islam, Universitas Islam Kalimantan MAB Banjarmasin \\ tutusuniska17gmail.com
}

\begin{abstract}
Abstrak
Penelitian ini bertujuan untuk mengetahui penerapan dalam keterampilan menulis cerita pada siwa kelas III di Madrasah Ibtidaiyah Darul Ilmi Banjarbaru setelah diterapkannya media gambar seri dalam proses pembelajaran. Adapaun penelitian ini memiliki dua rumusan masalah, yaitu: 1) Bagaimana penerapan Media Seri dalam Keterampilan Menulis Cerita di Madrasah Ibtidaiyah Darul Ilmi Banjarbaru, 2) Apakah penerapan media seri dapat meningkatkan keterampilan menulis cerita di Madrasah Ibtidaiyah darul Ilmi Banjarbaru. Metode penelitian menggunakan penelitian deskriptif kualitatif. Hasil penelitian menunjukan peningkatan keterampilan menulis cerita di madrasah Ibtidaiyah darul Ilmi Banjarbar. Berdasarkan hasil analisis, peserta didik yang memperoleh nilai di atas KKM sebanyak 27 orang dari 34 orang peserta didik, dengan persentase yang dihitung dengan rumus sebagai berikut : $\mathrm{N}$ $=27 / 34 \times 100 \%=79 \%$ dari 34 peserta didik. Sedangkan, peserta didik yang mendapat nilai dibawah KKM ( 75 ) sebanyak 7 peserta didik, dengan persentase yang dihitung dengan rumus sebagai berikut : $\mathrm{N}=$ $7 / 34 \times 100 \%=21 \%$ dari 34 pserta didik Kemampuan peserta didik di Madrasah Ibtidaiyah Darul Ilmi Banjarbaru, secara umum bisa dikatakan baik dari sebelumnya, peserta didik mampu menuangkan ide/gagasan dalam bentuk keterampilan menulis cerita dengan baik.

Kata Kunci: Media Gambar Seri, Keterampilan Menulis Cerita
\end{abstract}


Tutus Rani Arifa: Penerapan Media Gambar Seri dalam Keterampilan Menulis Cerita di Madrasah Ibtidaiyah Darul Ilmi Banjarbaru

\begin{abstract}
This study aims to find out the application of writing skills to stories in class III students at the Ibulidahyah Darul Ilmi Banjarbaru Madrasah after the application of serial image media in the learning process. This research has two formulation of the problem, namely: 1) How the application of the Series Media in Writing Story Skills in Darul Ilmi Banjarbaru Ibtidaiyah Madrasas, 2) Is the application of serial media can improve story writing skills in Ibtidaiyah Darul Ilmi Banjarbaru Madrasah The research method uses qualitative descriptive research. The results of the study showed an increase in story writing skills at the Ibtidaiyah darul Ilmi Banjarbaru madrasah. Based on the results of the analysis, the students who scored above the KKM were 27 people out of 34 students, with the percentage calculated as follows: $N=27 / 34 x$ $100 \%=79 \%$ of 34 students. Meanwhile, students who scored under the KKM (75) were 7 students, with percentages calculated using the following formula: $N=7 / 34 x 100 \%=21 \%$ of 34 students educating Ability of students in Madrasah Ibtidaiyah Darul Ilmi Banjarbaru, in general it can be said to be good than before, students are able to put ideas / ideas in the form of writing stories well.
\end{abstract}

Keywords: Series Image Media, Story Writing Skills

Al-Madrasah: Jurnal Ilmiah Pendidikan Madrasah Ibtidaiyah

Vol. 3, No. 2, Januari-Juni 2019 
Tutus Rani Arifa: Penerapan Media Gambar Seri dalam Keterampilan Menulis Cerita di Madrasah Ibtidaiyah Darul Ilmi Banjarbaru

\section{A. Pendahuluan}

Bahasa Indonesia memiliki peranan yang sangat penting. Bahasa Indonesia merupakan salah satu mata pelajaran yang menjadi dasar untuk mempelajari mata pelajaran yang lain. Bahasa Indonesia mencakup dua keterampilan berbahasa yang meliputi keterampilan bahasa lisan dan keterampilan bahasa tulis. Keterampilan bahasa lisan meliputi apsek keterampilan berbicara dan menyimak. Keterampilan bahasa tulis meliputi aspek keterampilan membaca dan menulis. Keempat aspek keterampilan itu pada dasarnya merupakan satu kesatuan yang saling berhubungan.

Keterampilan menulis sebagai salah satu dari keempat aspek keterampilan yang merupakan kegiatan produktif dan ekspresif. Menulis adalah suatu proses penyampaian gagasan, pesan, sikap, dan pendapat kepada pembaca dengan lambang bahasa untuk mencapai maksud dan tujuan. Keterampilan menulis seseorang tidak hanya diperoleh secara alami tetapi melalui kegiatan belajar mengajar. Keterampilan menulis ini dapat dicapai dengan latihan dan bimbingan yang intensif. Hal tersebut senada dengan apa yang dikatakan oleh Tarigan bahwa keterampilan hanya dapat diperoleh dan dikuasai dengan jalan praktik dan banyak pelatihan.

Untuk itu, seyogyanya pembelajaran dilakukan dengan berbagai cara untuk memudahkan siswa dalam mencapai kompetensi yang sesuai dengan tujuan yang telah dirumuskan. Salah satu caranya adalah dengan penggunaan media. Menurut Gagne dalam Sadiman, bahwa media adalah berbagai jenis komponen dalam lingkungan siswa yang dapat merangsangnya untuk belajar.

Media gambar merupakan salah satu media pembelajaran dalam pengajaran bahasa Indonesia, media mempunyai peran penting karena beberapa alasan. Media pembelajaran membantu guru dalam mengatur proses pengajarannya serta penggunaan waktu di kelas dengan bijak. Media pembelajaran yang biasa digunakan meliputi permainan, gambar, komik, CD dan sebagainya. Ketersediaan media di suatu kelas akan mempengaruhi pembelajaran siswa dimana penempatan media yang sesuai akan mendukung 
Tutus Rani Arifa: Penerapan Media Gambar Seri dalam Keterampilan Menulis Cerita di Madrasah Ibtidaiyah Darul Ilmi Banjarbaru

proses pencapaian pembelajaran itu sendiri salah satunya adalah menggunakan media gambar.

Menurut Ahmad Rohani mengatakan bahwa media gambar adalah media yang merupakan reproduksi bentuk aslinya dalam dua dimensi, yang berupa foto atau lukisan. Media gambar seri memberikan kontribusi yang baik kepada siswa untuk meningkatkan motivasi siswa dalam menulis cerita. Selain itu, siswa mampu mengurutkan gambar tersebut sesuai dengan konteks yang tertera pada gambar. Dengan menggunakan media gambar, siswa terfokus pada satu pembahasan yang disampaikan oleh gurunya, sehingga media gambar seri merupakan pembelajaran yang efektif.

Lubis dalam Bonef menjelaskan bahwa gambar seri adalah salah satu alat masa yang memberi pendidikan untuk kanak-kanak maupun orang dewasa.

Pembelajaran akan berhasil adanya media penyampaian yang dilakukan oleh guru sebagai alat mentransfer ilmu kepada siswa. Salah satu media sebagai pendukung proses pembelajaran dalam bahasa Indonesia yakni media gambar seri. Dengan menggunakan media gambar seri, siswa terfokus pada tema yang telah ditentukan oleh guru, sehingga ide/gagasan pada cerita lebih jelas. Jadi, dari pembahasan di atas dapat disimpulkan bahwa media gambar seri merupakan perantara berupa gambar bersambung dan berurutan peristiwanya yang digunakan untuk menyampaikan pesan sehingga mempermudah siswa dalam mengamati secara langsung. Selain itu, media gambar seri juga memberikan kontribusi yang baik kepada siswa untuk meningkatkan motivasi siswa dalam menulis cerita

Berdasarkan latar belakang tersebut, maka penulis tertarik untuk meneliti tentang media gambar seri dalam keterampilan menulis cerita. Penelitian ini akan dituangkan dalam sebuah karya ilmiah dengan judul "Penerapan Media Gambar Seri Dalam Keterampilan Menulis Cerita Di Madrasah Ibtidaiyah Darul Ilmi Banjarbaru”. 
Tutus Rani Arifa: Penerapan Media Gambar Seri dalam Keterampilan Menulis Cerita di Madrasah Ibtidaiyah Darul Ilmi Banjarbaru

\section{B. Metode Penelitian}

\section{Jenis Penelitian}

Penelitian ini penulis menggunakan penelitian deskriptif kualitatif. Penelitian deskriptif kualitatif adalah prosedur penelitian yang menghasilkan data deskriptif berupa kata-kata tertulis atau lisan dari orang-orang dan perilaku yang dapat diamati dari sumber data. Pendekatan kualitatif deskriptif adalah penelitian yang dimaksudkan untuk memahami fenomena tentang apa yang dialami oleh subjek penelitian; misalnya perilaku, persepsi, tindakan dan lainlain, secara holistik dan dengan cara deskripsi dalam bentuk kata-kata dan bahasa, dalam suatu konteks khusus yang alamiah dan dengan memanfaatkan berbagai metode ilmiah.

Pengumpulan data sangat penting bagi penelitian, sebab teknik pengumpulan data mendukung keberhasilan dalam suatu penelitian. Adapun teknik yang digunakan adalah Penelitian lapangan (field research), penelitian ini dilakukan untuk memperoleh data secara langsung kelapangan melalui : Observasi, Teknik tes (tertulis)

\section{Lokasi Penelitian}

Penelitian ini dilakukan di Madrasah Ibtidaiyah Darul Ilmi Banjarbaru

\section{Data dan Sumber Data}

Objek dalam penelitian ini adalah keterampilan menulis cerita yang dibuat oleh peserta didik, pemilihan tersebut akan merangsang imajinasi peserta didik dalam menulis cerita, peneliti mengambil sampel kelas III yang berjumlah 34 peserta didik. Maka demikian peneliti dapat mengetahui keterampilan peserta didik dalam menulis cerita di Madrasah Ibtidaiyah Darul Ilmi Banjarbaru.

Observasi dilakukan untuk mengamati pelaksanaan pembelajaran yang sedang dilaksanakan. Untuk melihat perkembangan peserta didik dalam menulis karangan persuasi dengan menggunakan media gambar peneliti menggunakan lembar observasi yang digunakan untuk mengemukakan data terkait dengan perkembangan siswa dalam menulis karangan persuasi. Selain 
Tutus Rani Arifa: Penerapan Media Gambar Seri dalam Keterampilan Menulis Cerita di Madrasah Ibtidaiyah Darul Ilmi Banjarbaru

itu observasi juga dilakukan dengan cara mencatat hal-hal penting pada saat pembelajaran berlangsung.

Setelah observasi dilakukan selanjutnya peneliti menggunakan teknik tes. Teknik tes digunakan untuk mengetahui keterampilan peserta didik dalam menulis karangan persuasi, ketika peserta didik melihat tayangan dari media gambar diharapka mampu menulis karangan persuasi sebanyak dua Paragraph atau lebih, untuk mengetahui apakah media tersebut mampu merangsang imajinasi peserta didik atau tidak.Setelah observasi dan teknik tes dilakukan kepada semua peserta didik kelas III.

\section{Teknik Pengumpulan}

Dalam pengumpulan data, peneliti menghimpun data secara empiris. Dari data tersebut dimaksudkan untuk memahami ragam kegiatan yang dikembangkan menjadi suatu pola temuan peneliti, pola temuan tersebut selanjutnya diverifikasikan dengan menguji kebenaranya bertolak pada data baru yang spesifik Teknik pengumpulan data yang digunakan dalam penelitian ini adalah:

\section{a. Observasi}

Observasi dilakukan untuk mengamati pelaksanaan pembelajaran yang sedang dilaksanakan. Untuk melihat perkembangan peserta didik dalam menulis karangan persuasi dengan menggunakan media gambar peneliti menggunakan lembar observasi yang digunakan untuk mengemukakan data terkait dengan perkembangan siswa dalam menulis karangan persuasi. Selain itu observasi juga dilakukan dengan cara mencatat hal-hal penting pada saat pembelajaran berlangsung.

\section{b. Teknis Tes}

Teknik tes digunakan untuk mengetahui keterampilan peserta didik dalam menulis karangan persuasi, ketika peserta didik melihat tayangan dari media gambar diharapka mampu menulis karangan persuasi sebanyak dua Paragraph atau lebih, untuk mengetahui apakah media tersebut mampu 
Tutus Rani Arifa: Penerapan Media Gambar Seri dalam Keterampilan Menulis Cerita di Madrasah Ibtidaiyah Darul Ilmi Banjarbaru

merangsang imajinasi peserta didik atau tidak.Setelah observasi dan teknik tes dilakukan kepada semua peserta didik kelas III.

\section{Teknik Analisis Data}

Penulis menggunakan metode deskriptif kualitatif yaitu analisis data dilakukan dengan menata dan menelah secara sistematis semua data yang diperoleh. Penelitian deskriptif adalah penelitian yang menggunakan suatu peristiwa, gejala, kejadian, yang terjadi pada saat sekarang, artinya penelitian deskriptif adalah mengambil masalah atau memusatkan perhatian kepada masalah-masalah aktual sebagaimana adanya pada saat penelitian dilaksanakan. Penelitian yang semacam ini disebut dengan penelitian yang berusaha mencari informasi aktual yang mendetail yang menggambarkan identifikasi masalah atau mendapatkan justifikasi keadaan dan praktek yang sedang berlangsung.

Dalam melaksanakan penelitian ini, peneliti melalakukan persiapanpersiapan penelitian diantaranya dengan mengembangkan alat-alat pengumpulan data sesuai dengan tujuan penelitian yang telah ditetapkan, untuk mencari dan mendapatkan data yang dibutuhkan tersebut. Data tersebut dikumpulkan dalam aneka macam cara (observasi, tekniktes, Untuk mengolah data yang terkumpul, peneliti menggunakan teknik data kualitatif sebagai berikut:

a. Analisis data hasil observasi, yaitu data yang diperoleh berdasarkan kunjungan langsung dilokasi penelitian diolah dan dianalisis sehingga diperoleh data yang lebih akurat dan asli, sehingga fakta yang sesungguhnya dapat diungkap secara cermat dan lengkap.

b. Analisis data hasil teknik tes, teknik tes digunakan untuk mengetahui keterampilan peserta didik dalam menulis karangan persuasi, ketika peserta didik melihat tayangan dari media gambar peserta didik diharapkan mampu menulis karangan persuasi sebanyak dua paragraph atau lebih, untuk mengetahui apakah media tersebut mampu merangsang 
Tutus Rani Arifa: Penerapan Media Gambar Seri dalam Keterampilan Menulis Cerita di Madrasah Ibtidaiyah Darul Ilmi Banjarbaru

imajinasi peserta didik atau tidak. Data yang terkumpul kemudian dijadikan kesimpulan dari keseluruhan.

c. Dalam analisis data hasil teknik tes yang menjadi objek penelitian adalah peserta didik kelas III Madrasah Ibtidaiyah Darul Ilmi Banjarbaru yang berjumlah 34 peserta didik. Pemilihan media gambar tersebut untuk merangsang imajinasi peserta didik dalam keterampilan menulis cerita .

\section{Hasil dan Pembahasan}

1. Deskripsi Data Tes Keterampilan Menulis Cerita dengan

\section{Menggunakan Media Gambar Seri}

Nilai KKM yang harus di capai oleh peserta didik di kelas III adalah 75. Penggunaan media Gambar Seri sangat membantu dalam proses pembelajaran Bahasa Indonesia khususnya saat pembelajaran Keterampilan Menulis, dengan adanya media tersebut peserta didik dapat meningkatkan kemampuan menulis cerita dengan media gambar seri, hal ini terlihat dari nilai peserta didik, nilai peserta didik sebagian besar di atas nilai KKM, sedangkan mempraktikkan bacaan dan gerakan shalat tanpa media audio visual banyak peserta didik yang mendapatkan nilai di bawah KKM.

Berdasarkan hasil analisis, peserta didik yang memperoleh nilai di atas KKM sebanyak 27 orang dari 34 orang peserta didik, dengan persentase yang dihitung dengan rumus sebagai berikut : $\mathrm{N}=27 / 34 \times 100 \%=79 \%$ dari 34 peserta didik. Sedangkan, peserta didik yang mendapat nilai dibawah KKM ( 75 ) sebanyak 7 peserta didik, dengan persentase yang dihitung dengan rumus sebagai berikut : $\mathrm{N}=7 / 34 \times 100 \%=21 \%$ dari 34 pserta didik.

Kemampuan peserta didik di Madrasah Ibtidaiyah Darul Ilmi Banjarbaru , secara umum bisa dikatakan baik dari sebelumnya, peserta didik mampu menuangkan ide/gagasan dalam bentuk keterampilan menulis cerita dengan baik. Dengan demikian penggunaan media gambar seri tersebut mampu 
Tutus Rani Arifa: Penerapan Media Gambar Seri dalam Keterampilan Menulis Cerita di Madrasah Ibtidaiyah Darul Ilmi Banjarbaru

merangsang imajinasi agar lebih kreatifdalam menuangkan ide pikiran kedalam sebuah tulisan.

\section{Simpulan}

1. Keterampilan peserta didik dalam menulis cerita di kelas III mengalami peningkatan ( dilihat dari hasil KKM). Hasil tes yang diperoleh , peserta didik mampu mengembangkan keterampilan dalam menulis khususnya dalam menulis cerita pada gambar seri dan termasuk dalam interprestasi baik.

2. Berdasarkan table analisis keseluruhan, maka diperoleh nilai keterampilan menulis cerita melalui media gambar seri sebanyak 34 peserta didik , dan 27 diantaranya mencapai nilai KKM. Sedangkan 7 peserta didik mendapatkan nila di bahawah KKM. Hasil tes keterampilan menulis cerita melalui media gambar sei pada kelas III dalam interprestasi baik. Pengguanaan media gambar seri dapat merangsang imajinasi peserta didik agar lebih kreatif dalam menuangkan ide/ gagasan ke dalam sebuah tulisan, khususnya dalam keterampilan menulis cerita.

3. Berdasarkan hasil analisis, peserta didik yang memperoleh nilai diatas KKM dengan menggunakan media gambar seri dalam keterampilan menulis cerita sebanyak 27 peserta didik, dengan presentasi $\frac{27}{34}$ x $100 \%$ $=79 \%$ dari 34 peserta didik, sedangkan peserta didik yang mendapatkan nilai dibawah KKM sebanyak $\frac{7}{34}$ x $100 \%=21 \%$ dari 34 peserta didik. 
Tutus Rani Arifa: Penerapan Media Gambar Seri dalam Keterampilan Menulis Cerita di Madrasah Ibtidaiyah Darul Ilmi Banjarbaru

\section{Daftar Pustaka}

Al-Bugha, Musthafa Dib. Buku Pintar Transaksi Syariah; Menjalin Kerja Sama Bisnis dan Menyelesaikan Sengketanya Berdasarkan Panduan Islam. Jakarta: Hikmah, 2010.

Anshori, Abdul Ghofur. Penerapan Prinsip Syariah dalam Lembaga Keuangan, Lembaga Pembiayaan, dan Perusahaan Pembiayaan. Yogyakarta: Pustaka Pelajar, 2008.

Antonio, Muhammad Syafi'i. Bank Syariah: Dari Teori Ke Praktik. Jakarta: Gema Insani Press, 2001.

Anwar, Syamsul. Hukum Perjanjian Syariah; Studi tentang Teori Akad dalam Fikih Muamalat. Jakarta: Rajawali Pres. 2010.

Ascarya. Akad dan Produk Bank Syariah. Jakarta: PT. RajaGrafindo Persada, 2008.

Departemen Agama RI. Al-Qur'an dan Terjemahnya. Bandung: Diponegoro, 2008.

Diana, Ilfi Nur. Hadis-Hadis Ekonomi, Malang: UIN-Maliki Press, 2011.

Fatoni, Siti Nor. Pengantar Ilmu Ekonomi, Dilengkapi Dasar-Dasar Ekonomi Islam. Bandung: Pustaka Setia, 2014.

Karim, Adiwarman. Bank Islam; Analisis Fiqih dan Keuangan. Jakarta: PT Raja Grafindo Persada, 2006. 